\title{
Work-Family Conflict among Public and Private Sector College Teachers
}

\author{
Fauzia Khurshid $^{1}$ \\ Syeda Misbah Batool ${ }^{2}$
}

\begin{abstract}
The present study was designed to investigate work-family conflict experienced by public and private sector college teachers. Major objectives of this research were to investigate the existence of work and family conflict among college teachers and to determine the impact of college teachers' demographic variations of gender, designation, experience and working extra hours in determining direction of work family conflict. For data collection a work-family conflict scale consisted of 63 items was used. The sample consisted of 100 college teachers among them 50 were male teachers and 50 were female teachers. Data were collected through stratified random sampling technique. Results of this research revealed that teachers working in private sector universities were experiencing higher work family conflict; male college teachers of both sectors had higher work family conflict as compared to female college teachers of both sectors. Teachers who were designated as an Associate Professor had higher work family conflict as compared with Lecturer and Assistant Professors. It is recommended that management of private sector colleges may take necessary steps to reduce the work family conflict of college teachers. It is recommended that teachers who are suffering due to higher work family conflict may take psychotherapy and may learn the art of cognitive restructurings in order to save themselves from the adverse effects of work family conflict. It is also recommended that teachers must practice religion in their life and seek help from Allah Almighty for better resolution of work family conflict.
\end{abstract}

Keywords: Work-Family Conflict, Public and Private Sector, College Teachers, Demographic factors

\footnotetext{
${ }^{1}$ Visiting Faculty, National University of Modern Languages, Islamabad Email: dr_f_khurshid@yahoo.com

${ }^{2}$ Research Scholar, Department of Education, National University of Modern Languages Islamabad
} 


\section{Introduction}

Balancing responsibilities of the family and demand of the work is a constant apprehension for professionals, today every professional is busy than ever and the old concept of working hours during the weekdays has been changed. Now even after the working hours it's difficult for employees to forget about office demands until the next working day. One main reason of this shift is the advent of advanced information technology including cell phones, messages, internet access at home or anywhere we go. Due to the advent of information and communication technology, now it is not difficult to take the office on the road when traveling to home. Even at home, official errand scan inflict family time with a sudden call that may restrain the time to be had for the family. This absurdity between the anxiety of job and family concerns create role conflict and stress on today's' professionals. Researchers set apart the incongruity between the sphere of work and the sphere of family as work-family conflict. Conflict between these spheres comes about when involvement in one role is more complicated due to participation in the other role. Nowadays, work-family conflict (work interfering with family) is more widespread than family-work conflict (family interfering with work) though both can occur. However, despite of the direction of causation, when one sphere is inharmonious with another sphere, the result is conflict and increased stress on an individual (King, 2013).

\subsection{Research Objectives}

1. To investigate the existence of work family conflict among teachers working in private and public sectors colleges.

2. To determine the impact of college teachers' demographic variations of gender, designation, experience and working extra hours in determining level of work family conflict.

\subsection{Hypotheses}

$\mathbf{H}_{\mathbf{0 1}}$ : Teachers who are working in the public sector colleges are experiencing less work family conflict than those working in private sector colleges.

$\mathbf{H}_{\mathbf{0} 2}$ : The male college teachers are experiencing higher work family conflict than female college teachers.

$\mathbf{H}_{\mathbf{0} 3}$ : Experienced teachers can handle their work family conflict more effectively than less experienced one.

$\mathbf{H}_{\mathbf{0 4}}$ : Teachers who are doing extra hours work are experiencing more work family conflict than teachers who do not work extra hours.

$\mathbf{H}_{\mathbf{0} 5}$ : Teachers who are designated as Associate professors are experiencing more conflict than teachers who are designated as a lecturer.

$\mathbf{H}_{\mathbf{0 6}}$ : Teachers who are living with their spouse are experiencing less conflict than teachers who are separated or widowed. 


\section{Literature Review}

Greenhaus and Beutell (1985) were pioneers in the field of work-family conflict research, they viewed work-family conflict as a type of inter-roles conflict where work and family roles were unable to get along and seen as challenging for an individual's time, liveliness and behaviors on and off the work.

Anafarta and Kuruuzum (2012) carried out a study in order to investigate the impact of numerous biographical factors such as age, gender, marital status, socio economic status, number of kids and service of the life partner on family work conflict and work -family. Results revealed that level of work-family conflict was high in both of the genders (males and females) and no statistically significant difference was found between the mean score of male and female respondents. Logistic regression analysis demonstrated that work family conflict faced by males was negatively interrelated with job tenure and education but positively associated with marital status. Work-family conflict experienced by females was negatively correlated with education whereas it was positively correlated with marital status. Job tenure had an impact on family-work conflict of males while age of children and taking care elderly parents were noted to have an impact on family-work conflict of females. It is generally observed that female professional may also be more likely to take time off from work to care for a sick child than their male counterparts. In order to accommodate maternal issues of female workers, maternity leave of three months is given after that mother of new born have to rejoin job. Working mothers can face more problems at working place, due to challenge perceptions and stereotypes that can start as a working woman becomes a working mother. Working mothers having children are supposed as less capable and less worthy of training than childless women. The factor of absenteeism is mostly present in working mothers because they face health issue regarding their children. They are considered as less favorite in any organization.

Change (2011) conducted a study to investigate that how to identify the influence of work-family conflict and sex-role in married female teachers' job involvement. The researcher concluded that married female teachers showed lower job involvement due to the high work-family conflict group as compared with those in the low work-family conflict group. Results showed that to increase married female teacher's job involvement, psychological changes for women are compulsory. In this context a study was carried out by Ansari (2012) to explore the existing differences between work-to-family interference, and family-to-work interference between male and female employees. Research study concluded that there was no major gender difference existing between male and female in relation to work-family interference and family-to-work interference. 
Family and work continued to be important domains of our lives, and the interaction of both are critically important for employees and managers. In this context researchers had much accomplishment in encouraging both organizations and employees to distinguish the significance of achieving greater balance in lives of professionals. If some imbalance is present it will damage the organization in terms of effectiveness and efficiency and to the individual in terms of constant worry and poor quality of life.

Work family conflict is a kind of inter roles conflict in which the role stresses from the work and family spheres are reciprocally incompatible in some respect. Consequently involvement in the family role is more challenging by virtue of involvement in the work role (Greenhaus \& Beutell, 1985). Professionals are managing different roles simultaneously in life; while performing each role one cannot ignore the other role. Therefore, an individual might feel clash which results in attitudinal changes such as cynicism and arrogance which ultimately lead towards negativity, which can obstruct effective communication at work place. In addition to this professionals are also fulfilling their official and personal responsibilities. Long working hours, fewer salaries and no paid leaves make them stressed and aggressive. That is why they become a victim of mental stress due to single earner of their family.

The growing interest in understanding fully the interface of work and family roles and their antecedents has stimulated the development of a predictive model of work-family conflict. Ahmad (2008) developed a model on predictors of work-family conflict which suggests that the predictors could be job-related (job type, work time commitment, job involvement, role overload, job flexibility), family-related (number of children, life-cycle stage, family involvement, child care arrangements) and individual-related (life role values, gender role orientation, locus of control and perfectionism).

Teaching is a noble profession which requires expertise from professionals. Along with teaching college teachers are generally engaged in research and management related activities, while performing these duties teachers some time fail to construct a balance between their work role and family roles (Arreola, 2000).

\subsection{Population and Sample}

\section{Research Methodology}

Study was descriptive and quantitative in nature which was carried out to measure the work family conflict experienced by teachers working in private and public sector colleges. The population of the study comprised of male and female teachers of private and public Graduate and Post Graduate Colleges. A stratified random sample of 100 college teachers was collected from two public sector and 
two private sector colleges (Federal Government College for Women Islamabad F-7/2 Islamabad, Punjab College of Commerce Islamabad, and Islamabad Model College for Boys I-10/1 Islamabad and Punjab College of Commerce Islamabad).

Age of teachers ranged from 25 to 50 years and their job experience ranged from 1 to 25 years. Data were collected from teachers those were teaching various subjects including Urdu, Physics, Chemistry, Islamiat, Statistic, Biology, Education, English, Computer Science, Pakistan Studies and Mathematics.

\subsection{Research Instrument}

For the measurement of work family conflict an indigenous work family conflict scale was developed by the researchers through standardized process. It was comprised of 63 items and four subscales named: conflict due to personal factors, conflict due to work, conflict due to family pressures, conflict due to lack of time. Likert type five point rating scale was used as response category.

\subsection{Data Collection}

Data were collected through a personal visit of the sampled colleges; respondents were instructed to rate each statement according to their own agreement and disagreement of each statement on Likert type 5 point rating scale.

\section{4. $\quad$ Results}

After data collection, it was analyzed with the help of statistical package of (SSPS) version 20.Reliability was determined through Alpha reliability coefficient and item total correlations were calculated to check the internal consistency of research scale; results revealed that all items have significant correlation with the total scale, which ranges from .327 to.852.

Table 4.1

Inter- Scales Correlations of Respondents Score on the Work-Family Conflict Scale $(\mathrm{N}=100)$

\begin{tabular}{lllll}
\hline $\begin{array}{l}\text { Work Family } \\
\text { Conflict }\end{array}$ & $\begin{array}{l}\text { Personal } \\
\text { Factors }\end{array}$ & $\begin{array}{l}\text { Conflict due } \\
\text { to Work }\end{array}$ & $\begin{array}{l}\text { Conflict due } \\
\text { to Family }\end{array}$ & $\begin{array}{l}\text { Conflict due } \\
\text { to Lack Time }\end{array}$ \\
\hline $\begin{array}{l}\text { Conflict due to } \\
\text { Personal Factors } \\
\text { Conflict due to }\end{array}$ & .528 & & & \\
$\begin{array}{l}\text { Work } \\
\text { Conflict due to }\end{array}$ & .659 & .623 & & \\
$\begin{array}{l}\text { Family Pressures } \\
\text { Conflict due to }\end{array}$ & .591 & .536 & .537 & \\
$\begin{array}{l}\text { Lack of Time } \\
\text { Total }\end{array}$ & .886 & .825 & .765 & .769 \\
\hline
\end{tabular}


Table 4.1 shows that the inter scales correlation of subscales with total scale, it ranges from .765 to .886 .it shows that subscale personal has higher correlation with total scale whereas, and subscale family has lower correlation with total scale.

Table 4.2

Mean and SD of Respondents Scores on the Variables "Sector" $(\mathrm{N}=100)$

Teachers of Public Sector Teachers of Private Sector

\begin{tabular}{|c|c|c|c|c|}
\hline $\begin{array}{l}\text { Work family } \\
\text { Conflict }\end{array}$ & Mean & SD & Mean & SD \\
\hline $\begin{array}{l}\text { Conflict due to } \\
\text { Personal } \\
\text { Factors }\end{array}$ & 72.1 & 10.2 & 82.8 & 15.1 \\
\hline $\begin{array}{l}\text { Conflict due to } \\
\text { Work }\end{array}$ & 57.5 & 9.8 & 63.6 & 10.3 \\
\hline $\begin{array}{l}\text { Conflict due to } \\
\text { Family } \\
\text { Pressures }\end{array}$ & 14.2 & 4.3 & 17.0 & 3.1 \\
\hline $\begin{array}{l}\text { Conflict due to } \\
\text { Lack of Time }\end{array}$ & 49.3 & 5.4 & 51.3 & 6.5 \\
\hline Total & 193.2 & 26.7 & 214.8 & 35.0 \\
\hline
\end{tabular}

Table 4.2 shows the Mean and Standard deviation of private and public sector college teachers sore on work family conflict scale. Results shows that teachers those are working in Private sector colleges are experiencing higher work family conflict as compared to teachers working in the public sector colleges. This table provides us interesting information that teachers working in private sector colleges are experiencing higher work family conflict on all subscales as compared to teachers those working in the public sector colleges.

Table 4.3

Mean and SD of Respondents' Scores on the Variables "Gender" (N=100) Male College Teachers Females College Teachers

\begin{tabular}{|c|c|c|c|c|}
\hline $\begin{array}{c}\text { Work family } \\
\text { conflict }\end{array}$ & Mean & SD & $\overline{\text { Mean }}$ & $\mathrm{SD}$ \\
\hline $\begin{array}{l}\text { Conflict due to } \\
\text { Personal Factors }\end{array}$ & 77.4 & 13.9 & 78.1 & 14.5 \\
\hline $\begin{array}{l}\text { Conflict due to } \\
\text { Work }\end{array}$ & 60.5 & 10.5 & 56.4 & 11.2 \\
\hline $\begin{array}{l}\text { Conflict due to } \\
\text { Family Pressures }\end{array}$ & 15.6 & 4.0 & 15.8 & 2.7 \\
\hline
\end{tabular}




\begin{tabular}{lcccc}
\hline $\begin{array}{l}\text { Conflict due to Lack } \\
\text { of Time }\end{array}$ & 50.3 & 6.0 & 47.7 & 6.1 \\
Total & 204.8 & 34.4 & 187.0 & 34.5 \\
\hline
\end{tabular}

Table 4.3 describes the Mean and Standard deviation of male and female college teachers, it can be seen from the table that male teachers are experiencing more work family conflict as compared to female college teachers.

Table 4.4

Mean and SD of Respondents' Scores on the Variables "Work Experience" $(\mathrm{N}=100)$

Less than 1 year $\quad 2$ to 5 years $\quad 6$ to $10 \quad 11$ years and above

\begin{tabular}{|c|c|c|c|c|c|c|c|c|}
\hline $\begin{array}{l}\text { Work family } \\
\text { Conflict }\end{array}$ & Mean & SD & Mean & SD & Mean & $\mathrm{SD}$ & Mean & SD \\
\hline $\begin{array}{l}\text { Conflict due to } \\
\text { Personal } \\
\text { Factors }\end{array}$ & 88.4 & 24.2 & 76.9 & 10.5 & 76.1 & 12.6 & 75.0 & 8.8 \\
\hline $\begin{array}{l}\text { Conflict due to } \\
\text { Work }\end{array}$ & 55.7 & 13.4 & 60.5 & 10.7 & 57.4 & 11.6 & 59.8 & 8.5 \\
\hline $\begin{array}{l}\text { Conflict due to } \\
\text { Family } \\
\text { Pressures }\end{array}$ & 17.7 & 3.3 & 16.3 & 2.9 & 15.3 & 3.4 & 14.5 & 3.4 \\
\hline $\begin{array}{l}\text { Conflict due to } \\
\text { Lack of Time }\end{array}$ & 48.2 & 9.9 & 50.1 & 5.6 & 48.5 & 5.5 & 49.0 & 5.0 \\
\hline Total & 210.0 & 50.8 & 203.9 & 23.8 & 197.4 & 30.7 & 198.5 & 22.1 \\
\hline
\end{tabular}

Table 4.4 describes the Mean and Standard deviation of the teachers' scores in relation with different work experience. Results revealed that teachers with less work experience are having higher work family conflict as compared to teachers with more work experiences.

Table 4.5

Mean and SD of Respondents' Scores on the Variable "Working Extra Hours" $(\mathrm{N}=100)$

Extra hours

Regular hours

\begin{tabular}{lcccc}
\hline Work family Conflict & Mean & SD & Mean & SD \\
\hline Conflict due to Personal & 78.0 & 10.9 & 77.6 & 14.1 \\
Factors & & & & \\
Conflict due to Work & 62.0 & 10.3 & 58.5 & 11.0 \\
Conflict due to Family & 15.9 & 3.2 & 15.7 & 3.4 \\
\hline
\end{tabular}




\begin{tabular}{lcccc}
\hline $\begin{array}{l}\text { Pressures } \\
\text { Conflict due to Lack of }\end{array}$ & 54.8 & 5.2 & 49.0 & 6.2 \\
$\begin{array}{l}\text { Time } \\
\text { Total }\end{array}$ & 210.7 & 24.5 & 201.1 & 29.0 \\
\hline
\end{tabular}

Table 4.5 shows the total Mean and Standard deviation of the respondents score on the variables working extra hour. From the table it can be seen that teachers working extra hours are experiencing higher work family conflict as compared to teachers who do not work extra hours (part time jobs).

Table 4.6

Mean and SD of Respondents' Scores on the Variables "Designation" (N=100)

Lecturers Assistant Professors Associate Professors

\begin{tabular}{lcccccccc}
\hline $\begin{array}{l}\text { Work family } \\
\text { Conflict }\end{array}$ & Mean & SD & Mean & SD & Mean & SD & Mean & SD \\
\hline $\begin{array}{l}\text { Conflict due } \\
\text { to Personal }\end{array}$ & 78.6 & 15.0 & 75.3 & 10.0 & 77.5 & 9.1 & 74.6 & 12.9 \\
$\begin{array}{l}\text { Factors } \\
\begin{array}{l}\text { Conflict due } \\
\text { to Work }\end{array}\end{array}$ & 58.4 & 11.2 & 57.4 & 8.8 & 65.0 & 7.0 & 60.5 & 13.7 \\
$\begin{array}{l}\text { Conflict due } \\
\text { to Family }\end{array}$ & 16.0 & 3.3 & 15.0 & 2.7 & 15.5 & 2.1 & 14.6 & 4.9 \\
$\begin{array}{l}\text { Pressures } \\
\text { Conflict due }\end{array}$ & 48.6 & 6.6 & 49.0 & 4.5 & 52.5 & 4.9 & 51.5 & 4.8 \\
$\begin{array}{l}\text { to Lack of } \\
\text { Time }\end{array}$ & & & & & & & & \\
Total & 201.7 & 30.1 & 196.9 & 20.8 & 210.5 & 23.3 & 201.4 & 33.7 \\
\hline
\end{tabular}

Table 4.6 shows the Mean and Standard deviation of teachers in relation with their designations (Lecturer, Assistant Professor, Associate Professor and Professor). Results show that Associate professors are experiencing higher work family conflict as compared to Lecturers, Assistant Professors and Professors. They are experiencing conflict due to more work. 
Table 4.7

Mean and SD of respondents Scores on the Variables "Marital Status" $(\mathrm{N}=100)$

\begin{tabular}{|c|c|c|c|c|c|c|}
\hline & \multicolumn{2}{|c|}{ Living with Spouse } & \multicolumn{2}{|c|}{ Separated } & \multicolumn{2}{|c|}{ Widows/Widowers } \\
\hline $\begin{array}{l}\text { Work family } \\
\text { Conflict }\end{array}$ & Mean & $\mathrm{SD}$ & Mean & $\mathrm{SD}$ & Mean & SD \\
\hline $\begin{array}{l}\text { Conflict due to } \\
\text { Personal Factors }\end{array}$ & 70.4 & 13.7 & 68.5 & 20.8 & 78.7 & 12.3 \\
\hline $\begin{array}{l}\text { Conflict due to } \\
\text { Work }\end{array}$ & 55.5 & 10.5 & 53.3 & 16.1 & 62.5 & 11.7 \\
\hline $\begin{array}{l}\text { Conflict due to } \\
\text { Family Pressures }\end{array}$ & 10.6 & 3.3 & 16.6 & 4.0 & 16.0 & 4.3 \\
\hline $\begin{array}{l}\text { Conflict due to } \\
\text { Lack of Time }\end{array}$ & 49.3 & 5.4 & 56.0 & 13.9 & 47.5 & 5.9 \\
\hline Total & 185.91 & 27.0 & 194.5 & 52.2 & 204.7 & 29.1 \\
\hline
\end{tabular}

Table 4.7 presents the Mean and Standard deviation for three types of marital status. Results show that widows/widowers are experiencing higher work family conflict as compared to teachers of who are living with their spouses or even separated.

\section{Discussion}

Several studies have been carried out in recent years about the antecedents and consequences of the conflict between work and family roles. Failure in balancing two vital components of life, namely work and family, is likely to lead to increase in work family conflict. Research indicates that work family conflict brings about numerous negative outcomes in work and family domains, some of which are exhaustion, anxiety, high blood pressure, low satisfaction from marriage, poor role performance, low professional well-being, life dissatisfaction, low organizational commitment, work dissatisfaction, burnout, desire to quit and high turnover (Friedman \& Greenhaus 2010).

Present study was designed to explore the work family conflict among teachers of public and private sector colleges. First objective of the study was to investigate the existence of work family conflict among college teachers. The second objective of the study was to determine the impact of demographic variation such as gender, designation, experience and working extra hours in determining the level of work family conflict among the college teachers. In this study various hypotheses were formulated to test the research objectives.

First hypothesis of the study was formulated to see the impact of sector in determining the level of work family conflict. The result confirms that teachers 
those were working in the private sector colleges were experiencing higher work family conflict as compared to the teachers working in the public sector colleges.

Second hypothesis of the study was, male college teachers are experiencing higher work family conflict than female college teachers. Analogous to many other countries, Pakistan has also experienced several changes in female employment participation and the number of couples with dual career has been increasing in the past few years. This transform has led to a significant variation in the number and variety of family roles like spouse, parent or caretaking of the elderly undertaken by the employees. The results of study confirm this hypothesis that male college teachers have experienced higher work family conflict as compared to female college teachers. As far as previous research study in this area is concerned a study was carried out in Antalya on employees of manufacturing and service sectors, results found that level of work-family conflict of males and females was almost same (high), and no statistically meaningful difference was found between their means. However logistic regression analysis revealed that the males' work-family conflict was negatively correlated with education and job tenure, but positively correlated with marital status whereas females work-family conflict was negatively correlated with education whereas, it was positively correlated with marital status (Audrey, 2012).

The third hypothesis of the study stated that experienced teachers can handle their work family conflict more effectively than less experienced ones. The result of the study confirms this hypothesis because teachers whose experience was less than one year were experiencing higher work family conflict.

The fourth hypothesis of the study was, teachers who are doing extra hours work are experiencing more work family conflict than teachers who do not work extra hours. Results make it clear that those are doing extra hours work are having higher work family conflict.

The fifth hypothesis was, teachers who are designated as Associate professors are experiencing more conflict than teachers who are designated as a lecturer. Results show that teachers designated as an associate professor are experiencing higher work family conflict as compared to teachers working on other designations. The sixth hypothesis was, teachers who are living with their spouse are experiencing less conflict than teachers who are separated or widowed. The sixth hypothesis was, teachers living with their spouse are experiencing less conflict than teachers who are separated or widowed/widowers. Results supported this hypothesis because widows /widowers teachers were experiencing higher work family conflict as compared to teachers who were separated or living with life partners. 


\section{Conclusions}

1. Teachers working in the private sector colleges were experiencing higher work family conflict as compared to teachers working in public sector colleges.

2. Male college teachers of both sectors (public and private) were having higher work family conflict as compared to female college teachers of both sectors (public and private).

3. Teachers with less work experience were having higher work family conflict as experienced ones.

4. Teachers who were working extra hours (part time job)were facing higher work family conflict as compared to those were not working extra hours.

5. Teachers who were designated as an Associate Professor having higher work family conflict as compared to others designations.

6. Teachers who were living with their spouse are experiencing less work family conflict than who were living without life partners.

\section{Recommendations}

In fact when employees have less control over their own schedules, their stress levels increase and they may be forced to choose between work and family activities, and they may take stress home from their jobs or from family to work. Outcome of conflicts between work and family life could be affecting employees' attendance, attention, productivity, health and safety. No doubt work is an important aspect of life which obviously requires time and energy if work family conflict handled properly, work experiences improve the quality of life in the family sphere, because reduced work-family conflict can improve employees' work productivity along with organizational productivity.

\section{Based on conclusions some specific recommendations are as under:}

1. Teachers working in private sector were experiencing higher work family conflict so, it is recommended that private sector colleges may create a culture that assumes employees control on their own schedules.

2. Male teachers experienced higher work family conflict $t$; it is recommended that college management may provide work family conflict management training. They may also provide flexible timetable in order to cater their life role effectively.

3. The result for the variable "designation" showed that Associate Professors were having higher work family conflict as compared to others, so it is recommended that may provide flexible schedule, recognition and also manageable credit hours work.

4. For the variable of "working extra hours", it revealed that teachers who were doing extra hours work having higher work family conflicts as compared to 
those who are not working extra hours, so it is recommended that they must be paid adequately so they may not work extra hours. Moreover, Government may provide desirable pay packages and economic incentives to all teachers so they can manage their expenses effectively.

5. Results revealed that teachers who were living without spouse experienced higher work family conflict than teachers living with spouse it is therefore, recommended that college administration may arrange social evening and get together frequently so such teachers can take pleasure.

\section{Other Recommendations}

1. Physical exercise can facilitate to become more attentive therefore, it is recommended that teachers should spare some time for exercise even when their work schedule is packed, it may eventually facilitate them to restore their energy level and concentration.

2. In order to solve work family conflict effectively management can play its role too, by increasing work flexibility, management can modify solutions that work best for them, as opposed to "one size fits all" approach.

3. It is also recommended that teachers must learn art of resorting balance in the work and family responsibility; they must prioritize and plan daily activities, if they become skilled at time management this would lead them towards better conflict management.

4. Finally in order to create harmony in life, it is recommended that teachers may practice religion in their life and seek help from Allah Almighty in handling work family conflict more effectively.

\section{References}

Ahmad, A. (2008). Job, Family and Individual Factors as Predictors of WorkFamily Conflict. Journal of Human Resource and Adult Learning Vol. 4, Num. 1, 57 University Putra Malaysia

Anafarta, N. \&Kuruuzum, A. (2012).Demographic Predictors of Work-Family Conflict for Men and Women: Turkish Case, International Journal of Business and Management.

Ansari, S. (2012). Gender differences: Work family. Retrieved from www.iobm.edu.pk/pbr/pbr_1107/110707_genderdifferences.pdf.

Arreola, R.A. (2000). Developing a Comprehensive Faculty Evaluation System: 2nd ed. Anker Publishing, Bolton, MA. 
Audrey, J.W. (2012). Work-Life Balance is out of reach for many male and female scientists. Retrieved from chronicle.com/article/Work-LifeBalance-Is-Out-of/131111.

Change, M. K. (2011).The Influences of Work-family Conflict and Sex-role Identity on. Interdisciplinary Journal of Research in Business, 18-29.

Change, M.K. (2011).Work-life balance for men and women remains unequal/EIGE. News and events. News.

Friedman, S. D., \& Greenhaus, J. H. (2000). Work and family: Allies or enemies? What happens when business professionals confront life choices? Oxford: Oxford University Press.

Greenhouse, J. \& Beutell, N. 1985. Sources of conflict between work and family roles. Academy of Management Review, 10, 76-88.

King, L. J. (2013). Research review: work family conflict. International Journal of Leadership Studies. 